\title{
METAL-INDUCED PROTEIN DENATURATION: REGULARITIES, PATHOLOGICAL MANIFESTATIONS, AND IN VITRO MODELING
}

\author{
PopovychTetiana $^{1}$, Kizim Yaroslav ${ }^{2}$, Obernikhina Natalia ${ }^{3}$, Voroshylova Natalia ${ }^{4}$ \\ ${ }^{1}$ Bogomolets National Medical University \\ ${ }^{2}$ National Academy of Medical Sciences of Ukraine prof. O.S. Kolomiuchenko Insitute of Otolaryngology \\ ${ }^{3}$ Candidate of chemical sciences, Bogomolets National Medical University \\ ${ }^{4}$ Candidate of biological sciences, National Academy of Medical Sciences of Ukraine prof. O.S. \\ Kolomiuchenko Insitute of Otolaryngology
}

\begin{abstract}
: the ability of various metal ions to form complexes with proteins leads to the denaturation of the latter and the development of immune response. Such hapten effects cause the well-known phenomenon of nickel-allergic contact dermatitis. No less typical are side effects of gadolinium compounds, that are used as contrasts for magnetic resonance imaging, but cause the development of fibrosis. In both cases an important role belongs to the interaction of metal ions with collagen structures. The aim of our study was to compare in vitro effects of copper and nickel ions on destabilized products of collagen cleavage. Significant difference between these metals in their ability to induce aggregation at close to physiological $\mathrm{pH}$ values was shown. The influence on the aggregative process of the acidification of the medium was revealed. It was shown that destabilization of protein structure leads to the formation of highly stabilized $\beta$-stacked protein aggregates. Comparison of the obtained experimental data with the literature ones makes it possible to approach the understanding of individual mechanisms of toxic effects of metal ions on the human body.
\end{abstract}

Key words: $\underline{\text { hapten, }}, \underline{\text { metals/toxicity, protein denaturation, }} \underline{\text { hypersensitivity, fibrosis }}$

Introduction. Permanent rise of industrial burden on the environment causes the increase of the contact of living organisms with various toxic compounds. Among the various intoxicants of this kind a significant role belongs to ions of heavy metals, which differ by ability to accumulation, severity of the effects, and immense variety of mechanisms of action on the organism. One of these mechanisms is caused by the ability of metal ions to form the complexes with various components of biologically active molecules and damage their structure in this way. Such denaturation of proteins leads to alterations of their functional activity as well as to the development of immune response to denaturated structures. In this mode of action a metal ion plays the role of a hapten, i.e. a substance that binds to a biologically active molecule and stabilizes its denaturedandimmunogenic structure. The classic example of such kind of hapten effect is nickel-allergic contact dermatitis (Ni-ACD). It is detected by the contact of nickel-containing objects with human skin. The interaction of metals with biological fluids of the body (sweat, saliva, etc.) results in formatiom of free $\mathrm{Ni}^{2+}$ ions, that denature the body's proteins and cause a reaction of the immune system (Naumova, 2019; Morgan, 1989). This action is based on the ability of Nickel ions to form complexes with amines and amine-containing compounds (coordination number - mainly 6 , minor - 4). According to WHO data, Ni-ACD was observed in $8.6 \%$ of the human population in Central Europe (Thyssen et al., 2007). Similar, even much less common, effects are known for cobalt $\mathrm{Co}^{3+}$ and chromium $\mathrm{Cr}^{3+}$ ions (Bonefeld et al., 2015; Okazaki \& Gotoh, 2008). These ions also form stable complexes with amine nitrogens. In this case the ions of different metals show a pronounced synergistic effect, surpassing the action of the same type of ions (Okazaki \&Gotoh, 2008). In recent years more and more attention is paid to the hapten properties of gadolinium ions $\mathrm{Gd}^{3+}$, which due to f-level of its electron shell and the ability to accumulate in diseased organs acquire the properties of magnetic resonance imaging (Todd \& Kay, 2016). This dramatically increases the informativeness of MRI diagnosis, but a side effect of the use of $\mathrm{Gd}^{3+}$ compounds is the development of fibrosis the growth of specific tissue, which differs significantly from normal ones (Wagner et al., 2016). All these lead 
to a relentless interest for the mechanisms of hapten effects of metal ions, their influence on protein molecules and the functional consequences of the latter ones. For obvious reasons, the mechanisms of Ni-ACD are the most studied and some features of this pathology remain open. First of all, it should be noted the formation of sensitization in persons who have no contact with metal nickel and its alloys (Morgan, 1989). It's also not clear why an unbalanced immune response has a pronounced specificity and does not lead to polysensitization to a variety factors. It is also worth to notify the local character of Ni-ACD that cause irritiation of the skin on the area of direct contact with the nickel-exploring object only. All this allows us to make some assumptions about the mechanisms of formation and development of Ni-ACD. The pronounced local nature of these processes may be evidence of the key role of haptenic effects of Nickel ions on the insoluble component of the skin, the basis of which is collagen (Bella, 2016). This protein is able to bind strongly complex-forming metal ions, which, in particular, is utilized in the processes of the tanning of skin by compounds of chromium, zircon and titanium. The lack of the development of polysensitization and the presence of Ni-ACD in persons that wasn't in contact with Nickel may be evidence of a very limited number of immunogenic epitopes formed due to the hapten exposure of $\mathrm{Ni}^{2+}$ ions (Zabolotny \& Verevka, 2009). How to test these assumptions?

First of all, we should pay attention to the structure and metabolism of the main connective tissue protein collagen. There are more than two dozen varieties, which exist mainly in the form of fibrillar fibers with a complex multilevel structure (Fig. 1).

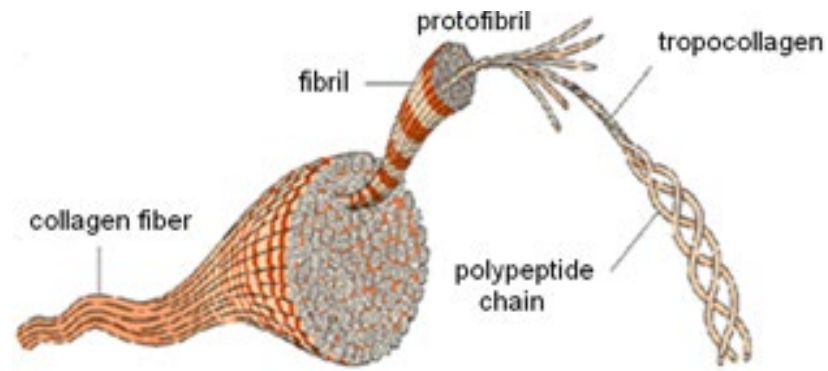

Fig. 1. The levels of collagen structure.

The structural subunit of collagen is tropocollagen a triple helix of polypeptide chains with a total molecular weight of about $300 \mathrm{kDa}$ with the diameter of 1.5 $\mathrm{nm}$ and a length of about $300 \mathrm{~nm}$. Collagen is a longlived protein whose half-life is determined by months. This creates the preconditions for damage to the surface layers of collagen fibrils by various factors that in vivo cause denaturation of proteins. These include proteolytic cleavage, damaging effects of reactive oxygen species and various non-functional associative processes (Verevka, 2017). Normally, damaged molecules are recognized and removed from circulation by the body's clearance systems. Contrary, the formation and local accumulation of significant amounts of structurally damaged proteins is the ordinary circumstance of various pathologies. The influence of the components of endogenous intoxication complicates the course of the disease, often exceeding the severity of the consequences of the original cause. This is due to both the violation of regulatory processes mediated by native forms of proteins, and the tendency of structurally damaged protein molecules to aggregation (Shevel \& Verevka, 2009). As were noted above, the lack of development of polysensitization by Ni-ACD may be a consequence of the formation of a very limited number of antigenic determinants. Such a restriction may be a consequence of regular structure formation of destabilized proteins. For this condition corresponds completely the process of formation of $\beta$-structured protein aggregates ( $\beta$-SPA). Such aggregates are formed at various pathologies, which are associated with impaired protein metabolism (Zabolotnyi et al., 2019). The most pronounced example of such aggregation is amyloidosis - a heterogeneous group of diseases in which normal proteins are rearranged with the formation of $\beta$-SPA deposits (Buxbaum\&Linke, 2012), but no less important is the participation of these processes in the development of fibrosis (Zabolotnyi et al., 2021). The formed protein deposits are characterized by a high content of $\beta$-structured protein where $\beta$-folded layers are oriented parallel to the main axis of the fibril, that form the basis of a stable unit (Fig.2).

Due to the regularity of the structure formation process, the antigenic epitopes exposed on the surface of the aggregate quite similar to each other, that may lead

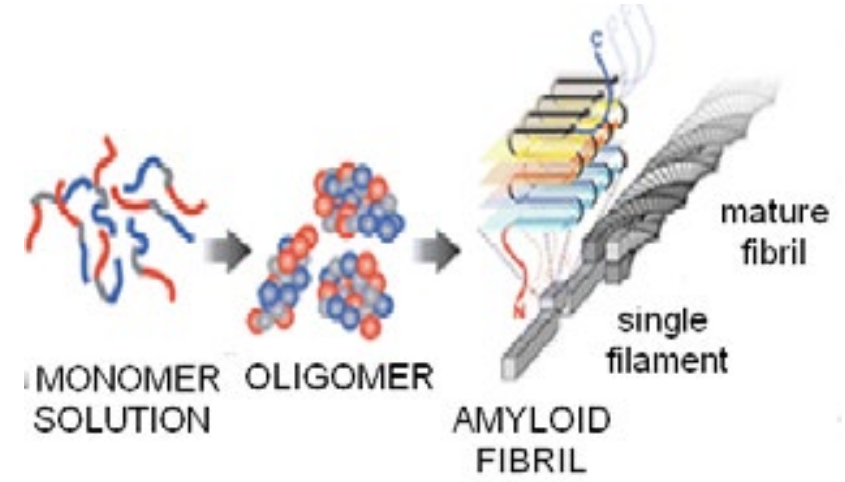

Fig. 2. The simplified scheme of autochthonous $\beta$-structured fibril self-assembly.

to the development of a limited response of the immune system. Does the haptenic effect of $\mathrm{Ni}^{2+}$ ions on collagen and its degradation products lead to the formation of $\beta$-structured protein aggregates and, as a consequence, the development of Ni-AKD? No less interesting is the question of the absence of allergic contact dermatitis under the action of copper. Like $\mathrm{Ni}^{2+}$ ions, $\mathrm{Cu}^{2+}$ ions are also able to form complex compounds with amines 
(coordination number - preferably 4, minor - 6). Copper ions differ little in toxicity from nickel ones since both belong to the same hazard group (Sanitarni normy San. PIN-4630-88). However, despite the constant contact of people with copper and its alloys, copper does not cause any significant allergic reactions. What causes the pronounced allergenic effect of nickel and the absence of such in copper? To clarify these issues, it seems appropriate to investigate the structure-forming effect of $\mathrm{Ni}^{2+}$ and $\mathrm{Cu}^{2+}$ ions on a model proteins whose native structure are more or less unbalanced. Gelatin, a product of thermal weakly acid or weakly alkaline cleavage of collagen, corresponds to such requirements fully. It is a heterogeneous mixture of protein fragments with a molecular weight of from 20 to $40 \mathrm{kDa}$. Gelatin molecules retain some residual structure of collagen (Fig. 3), and the ability to bind complex-forming metal ions (Mihajlov, 2000).

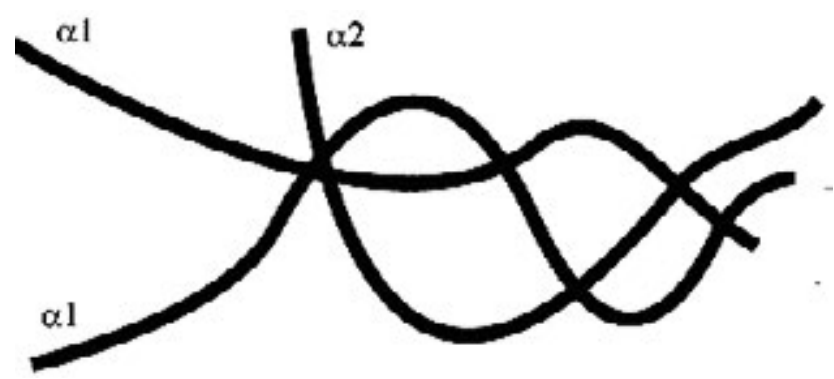

Fig. 3. Schematic representation of the gelatin molecule (Mihajlov, 2000).

In context of our study it is of interest to clarify two issues:

- are $\mathrm{Ni}^{2+}$ and $\mathrm{Cu}^{2+}$ ions able to induce the aggregation of gelatin?

- does such aggregation leads to formation of $\beta$-structured protein aggregates?

The answers for these questions may be got by various methods for protein structure study. Classical approaches include X-ray structural methods, methods of optical rotation dispersion and circular dichroism (Fraifedler, 1980). The difference in the spectral properties of $\beta$-SBA from other regular and irregular protein structures in infrared range makes it possible to detect the smallest number of $\beta$-structures. At the same time, the regularity of the structure of $\beta$-SPA led the development of optical methods based on the formation of chromogenic and fluorogenic groups at the interaction of the studied objects with highly selective dyes. As early as the 1920s, Congo red (CR) was introduced into research due to its capasity for selective binding of amyloid structures without noticeable interaction with healthy tissues (Brigger \& Muckle, 1975). This dye belongs to the vital ones and can be introduced into bloodstream for amyloidosis diagnosis (Bengold's test). In recent decades, mainly due to the growing interest in the molecular basis of central nervous system amyloidosis, a large number of chromogenic and fluorogenic compounds have been created that significantly exceed the CR by sensitivity (Inshyn et al., 2016). However, CR still remains for research, clinical and laboratory diagnostics. This is due to the following properties:

- the ability to interact with various soluble protein molecules without induction of associative processes and conformational rearrangements (Khuranaet al., 2001; Harris, 2012);

- the ability for selective and quantitative staining of $\beta$-structured aggregates in different shades of brick red without painting of healthy tissues, in particular - collagen (Brigger \&Muckle, 1975; Klunket al., 1989);

- CR painted $\beta$-SPA-containing tissues acquire different shades of apple-green color in polarizing microscopy (Buxbaum \& Linke, 2012);

- binding of CR by non-precipitating in the liquid micro- and nanoparticles of $\beta$-structured protein aggregates - both native and obtained ex vivo dramatically reduces their hydration and leads to precipitation (Buxbaum \& Linke, 2012; Voroshylovaet al., 2019). The latter circumstance allows in some extent to overcome the Abbe diffraction constraint, leaving invisible the objects less than 0.61 of light wavelengths.

Materials and methods. The study used the product of collagen degradation, gelatin (Merck, Germany), as an object for modeling protein aggregation processes. To destabilize the structure and promote the formation of the most stable denatured forms, an increase in temperature and an increase in the acidity of the medium in the range of $\mathrm{pH} 5.0$ - 7.4 were chosen. Such choice was conditioned by well-known range of human sweat acidity (from $\mathrm{pH} 3.8$ to 6.2). At inflammations the local acidification of tissues reaches 5.39-6.5, and in the intercellular space of malignant tumors - 6.2-6.9 contrary to 7.32-7.45 at norm. Rising temperature was selected experimentally. It exceeds the natural conditions significantly, but it should be noted the immense diversity of the composition proteins in blood and intercellular fluid, as well as the inreproducibility of the levels of their stabilization.

Studies of the aggregative influence of metal ions on the protein structure were performed according to the general scheme that was developed in our laboratory. All solutions were prepared in $0.9 \%$ sodium chloride with $0.2 \%$ sodium azide, which was added to prevent bacterial degradation of protein system. The influence of the following factors was studied: copper and nickel ions, $\mathrm{pH}$ and temperature. Preparation of the studied systems was performed to reach a final protein concentration of $10 \mathrm{mg} / \mathrm{ml}$. The $\mathrm{pH}$ values were adjusted to $5.5,6.0,6.5$, 7.0 and 7.4 by $0.2 \mathrm{~N} \mathrm{NaOH}$ or $0.2 \mathrm{~N} \mathrm{HCl}$ solutions. The final concentrations of copper and nickel ions were $10^{-4}$, $10^{-5}, 10^{-6}, 10^{-7}, 10^{-8}$, and $10^{-9} \mathrm{M}$. Such a tablet-like struc- 
ture of the samples allowed us to overlap the ranges of the studied values of $\mathrm{pH}$ and concentrations of ion metals. This set of protein solutions was incubated at $80^{\circ} \mathrm{C}$ for 36 hours and cooled to room temperarure.

To precipitate possible $\beta$-structured protein aggregates, $5.0 \mathrm{ml}$ of a $0.5 \%$ solution of Congo red in $0.9 \%$ sodium chloride was added to $0.5 \mathrm{ml}$ of the test solution and incubated at room temperature.

Congo Red dye and applied salts - qualifications not lower than analytical grade. Microscopic examinations were performed using an Olympus BX53 microscope (Japan) in light and polarization regimes.

Results and discussion. As well as were expected from the well-known properties of gelatin, after the incubation no visible aggregates were observed. This, however, did not exclude the possibility of their formation in micro- and nanoscale dimensiom, that are invisible in solution. In the presence of $\beta$-folded structures in

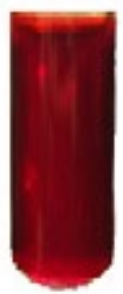

1

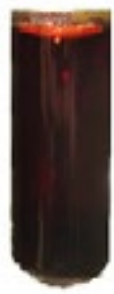

2

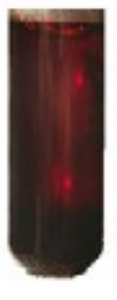

3

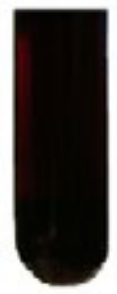

4

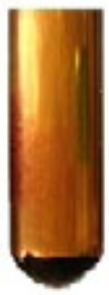

5

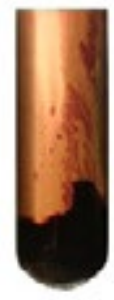

6
Fig.4. Precipitating effects of excess $\mathrm{CR}$ at $\mathrm{pH} 6.0$ and 5.5. 1 - $\mathrm{pH} 6.0$ in the absence of metal ions; 2 - $\mathrm{pH} 6.0$ in the presence of $10^{-4} \mathrm{M} \mathrm{Ni}^{2+}$ ions; $3-\mathrm{pH} 6.0$ in the presence of $10^{-4} \mathrm{M} \mathrm{Cu}^{2+}$ ions ; $4-\mathrm{pH} 5.5$ in the absence of metal ions; 5 - pH 5.5 in the presence of $10^{-4} \mathrm{M} \mathrm{Ni}^{2+}$ ions; $6-\mathrm{pH} 5.5$ in the presence of $10^{-4} \mathrm{M} \mathrm{Cu}^{2+}$ ions.

their composition, they may be detected by precipitation by Congo Red (Buxbaum \& Linke, 2012; Voroshylova et al., 2019). Due to incubation with Congo red for two days at room temperature, the formation of dark red precipitates was observed. The dependence of the nature of deposition on both $\mathrm{pH}$ and the nature of metal ions were revealed (Fig. 4).

As can be seen, at $\mathrm{pH} 6.0$ the formation of precipitates occurs in the presence of metal ions only. Contrary, at $\mathrm{pH} 5.5$, precipitation occurs even in the absence of the studied ions. That is the process of protein aggregation has a pronounced $\mathrm{pH}$-dependent nature, which is due to the destabilizing effect of environmental compression on the structure of proteins. This effect is not limited by soluble collagen cleavage products only. It is known that local acidification of the environment is an important factor in the destructive action of microbial biofilms (Malfertheiner et al., 2012; Zabolotnyi et al., 2019). Destabilizing effect of acidification is inherent for reflux, which leads to dysfunctional constriction of the larynx and causes damage to epithelial cells by destabilization of the protein component of the tissues of the larynx and due to $\mathrm{pH}$, that is favorable for pepsin action (Johnston et al., 2012; Deganello et al., 2015). The same acidification causes an increase of the proteolytic action of cathepsin D. This enzyme is a lysosomal proteinase released during the decay of tumor cells and whose increase in the bloodstream is a marker of the cancer (Kuteet al., 1992; Lou et al., 2007). At normal for the extracellular environment $\mathrm{pH}$ the activity of cathepsin $\mathrm{D}$ in the bloodstream is minor, where as at acidification to its $\mathrm{pH}$ optimum (4.5-5.0) its proteolytic action increases sharply.

It is worth noting the pronounced difference between the influence of nickel and copper ions at close to physiological $\mathrm{pH}$ values. Both at $\mathrm{pH} 7.4$ and 7.0 protein aggregation occurred only in the presence of $\mathrm{Ni}^{2+}$ ions, whereas no aggregation processes were noted in the presence of $\mathrm{Cu}^{2+}$ ones or in the absence of both (Fig. 5).

As can be seen, CR effectively precipitates microand nano-sized protein aggregates, and by this parame-
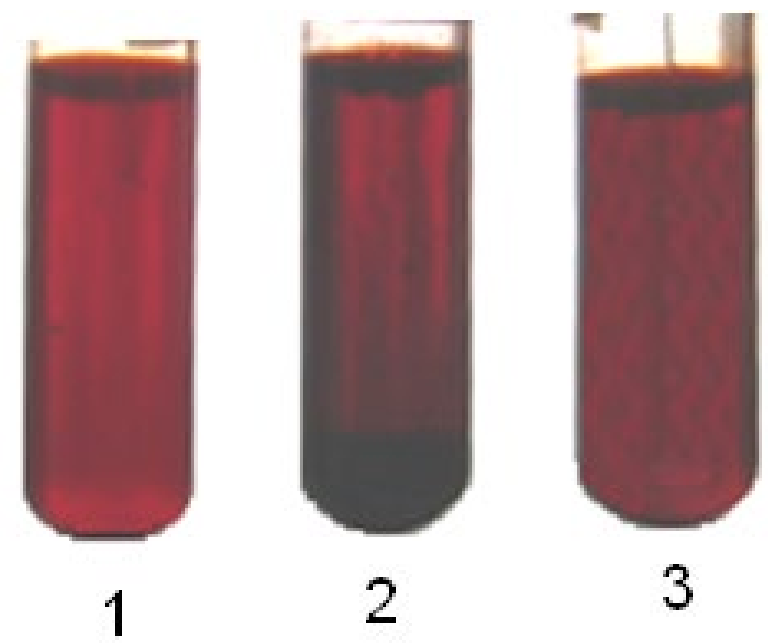

Fig. 5. Precipitating effects of CR excess on gelatin preparations at $\mathrm{pH}$ 7.0: 1 - in the absence of metal ions; 2 - in the presence of $10^{-4} \mathrm{M} \mathrm{Ni}^{2+}$ ions; 3 - in the presence of 10-4 $\mathrm{M} \mathrm{Cu}^{2+}$ ions.

ter $\mathrm{Ni}^{2+}$ ions exceed $\mathrm{Cu}^{2+}$ ions at close to physiological $\mathrm{pH}$ values. This may explain the formation of allergies to nickel and nickel-containing alloys and the absence of allergic effects of copper. It is known that the placement of nickel and copper in the electrochemical series of metals are different significantly:

\section{Li, K, Ba, Ca, Na, Mg, Al, Mn, Zn, Cr, Fe, Ni, Sn, Pb, Hz Cu, Hg, Ag, Pt, Au}

That's why copper does not dissolve in weak acids, which include sweat ( $\mathrm{pH}$ in the range of $3.8-6.2$ ). However, upon contact of biological fluids of organism with copper-nickel alloys in the soluble ionic form, both metals may be converted in ions. Our data indicate a crucial role of the differences in the complex-forming properties of these ions. This result corresponds well with the effects of gadolinium, chromium and cobalt ions. 
The question of the structural organization of the formed aggregates arises organically. Obviously, they should be formed in the direction of minimizing the free energy of the system and destabilizing of labile structures. The extreme and most energetically advantageous manifestation of such rearrangement is the formation of $\beta$-structured protein aggregates. Verification of the formation of such structures was prowed experimentally due to the properties of CR. As noted above, this dye is able to bind to protein molecules without initiating aggregation processes but is sorbed specifically and selectively by $\beta$-SBA. In this case the color of such adduct have be various shades of brick red in light microscopy, where as in polarizing one - green colour. This was exactly the picture we observed (Fig. 6).

In the light microscopy the color of the sediment in shades of brown color was observed, and in the polarizing one the typical for $\beta$-SBA apple-green color was

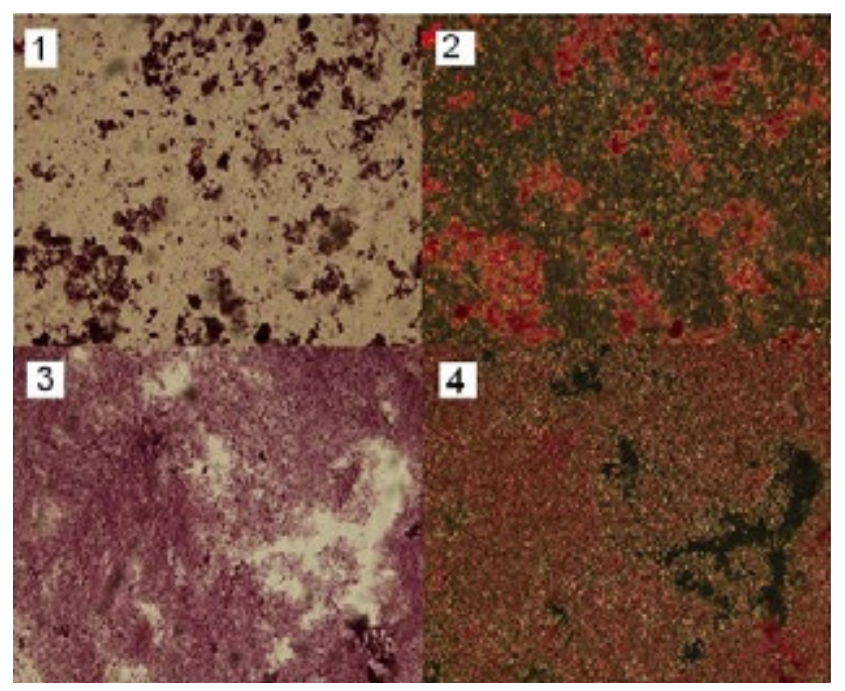

Fig.6. CR-colored gelatin precipitates formed at aggregation at $\mathrm{pH} 5.5$ and ion concentration $10^{-9}$ $\mathrm{M}$ : $1-\mathrm{Ni}^{2+}$ ions, light microscopy, $\times 200 ; 2-\mathrm{Ni}^{2+}$ ions, polarizing microscopy, $\times 200 ; 3-\mathrm{Cu}^{2+}$ ions, light microscopy, $\times 200 ; 4-\mathrm{Cu}^{2+}$ ions, polarizing microscopy, $\times 200$. observed (Fig. 6). This clearly indicates the formation of $\beta$-SBA. Aggregates formed in an acidic environment in the absence of the studied ions had a similar appearance.

Conclusions. The data obtained in in vitro experiments allow us to draw certain conclusions and generalizations about the mechanisms of denaturation of protein molecules by metal ions in vivo. It is shown that destabilized proteins tend to form stable $\beta$-structured aggregates, which are effectively detected by the specific dye Congo Red. The conductive factor that determines the hapten action of metal ions is their complexing properties. The level of stabilization of the structure of the corresponding protein is also important. Destabilization can be caused by proteolytic damage, various parametabolic processes, and acidification of the environment. The imprinted effects explain the allergic effects of nickel and nickel-containing alloys and the absence of these in copper. The influence of these factors is most pronounced in side effects of introduction of gadolinium compounds as the contraster for of magnetic resonance imaging. High complexing properties of this ion commonly with the local formation of significant amounts of damaged collagen and local acidification cause the accumulation of $\mathrm{Gd}^{3+}$ in the pathological tissue. At the same time, the complexing properties of gadolinium cause its denaturating effects, which leads to the progressive accumulation of protein aggregates and, as a consequence, to the development of fibrosis.

Financing. This study did not receive funding

Conflict of interest. None of the authors received research grants, speaker's fees from any companies and is not a member of commissions.

Authors contribution: concept, methodology, formal analysis - P.T., O.N.; research, resources, data curation, written - K.Ya., V.N.; original project preparation, review and editing, visualization, supervision, project administration, acquisition of financing - P.T., K.Ya., O.N., V.N.

Consent to publication. All authors have read and approved the final version of the manuscript. All authors have agreed to publish this manuscript.

\section{REFERENCES}

Bella, J. (2016). Collagen structure: new tricks of very old dog. Biochemical Journal, 473, 1001-1025.

Bonefeld, C., Nielsen, M., Vennegaard, M., Johansen, J., Geisler, C., Thyssen, J. (2015). Nickel acts as an adjuvant during cobalt sensitization. Experimental Dermatology, 24, 229-231.

Brigger, D., Muckle, T. (1975). Comparison of Sirius red and Congo Red as stains for amyloid in animal tissues. Journal of Histochemistry and Cytochemistry, 232, 84-88.

Buxbaum, J., Linke, R. (2012). A molecular history of the amyloidosis. Journal of Molecular Biology, 421, 142-159.

Deganello, A., Meccariello, G., Parrinello, G., Gallo, O. (2015). Laryngopharyngeal Reflux and Laryngeal Squamous Cell Carcinoma. Austin Journal of Cancer Clinical Research, 2, 1022.

Fraifedler, D. (1980) Fyzycheskaia byokhymyia. Moskow, Mir. [in Russian].

Harris, J.R., Ed., (2012). Interactions with Various Compounds. Protein Aggregation and Fibrillogenesis in Cerebral and Systemic Amyloid Disease. Springer Science \& Business Media. 
Inshyn, D.I., Chernii, S.V., Kovalska, V.B., Yarmoluk, S.M. (2016). Design of 4-(4-dialkylaminostyryl)-pyridinium dyes for fluorescent detection of amyloid fibrils. Biopolymers and Cell, 32, 289-299.

Johnston, N., Yan, J., Hoekzema, C., Samuels, T., Stoner, G., Blumin, J., Bock, J. (2012). Pepsin promotes proliferation of laryngeal and pharyngeal epithelial cells. Laryngoscope, 122, 15-22.

Khurana, R., Uversky, V., Nielsen, L., Fink, A. (2001). Is Congo red an amyloid-specific dye? Journal of Biological Chemistry, 276, 22715-22721.

Klunk W., Pettegrew J., Abraham D. (1989). Quantitative evaluation of Congo Red binding to amyloid-like proteins with beta-sheet conformation. Journal of Histochemistry and Cytochemistry, 37, 1273-1281.

Kute, T.E., Shao, Z.M., Snugg, N.K., Russeell, G.B., Case, L.D. (1992). Cathepsin D as prognostic indicator for node-negative breast cancer patient using both immunoassays and enzymatic assays. Cancer Research, 52, 198-203.

Lou, X., Xiao, T., Zhao, K, Wang, H., et al. (2007). Cathepsin D is secreted from M-BE cells: its potential role as a biomarker of lung cancer. Journal of Proteome Research, 6, 1083-1092.

Malfertheiner, P., Megraud, F., O’Morain, C.A., Atherton,J., Axon A.T., et al. (2012). Management of Helicobacter pylori infection. Gut; 61, 646-664.

Mihajlov, O.V. (2000). Zhelatin kak matrica v koordinacionnoj khimii. Priroda, 8, 57-63 [in Russian].

Morgan, L., Flint, G. (1989). Nickel alloys and coatings: release of nickel. In: Maibach H.I., Menne T. (eds)., Nickel and the skin: immunology and toxicology, CRC, Boca Raton, Fla, 45-54.

Naumova, O.A. (2019). Nickel allergy. Klinichna Imunolohiia Infektolohiia Alerholohiia, 2, 11-15. [in Russian].

Okazaki, Y, Gotoh, E. (2008). Metal release from stainless steel, $\mathrm{Co}-\mathrm{Cr}-\mathrm{Mo}-\mathrm{Ni}-\mathrm{Fe}$ and $\mathrm{Ni}-\mathrm{Ti}$ alloys in vascular implants. Corrosion Science, 50, 3429-3438.

Sanitarni normy i pravyla okhorony poverkhnevykh vod vid zabrudnennia. San.PIN-4630-88. [in Ukrainian].

Shevel, M.V., Verevka, S.V. (2009). The problems of protein preparations stability: molecular autodamages and their functional consequences. In: Molecular Pathology of Proteins (Zabolotny D.I., Ed.), NovaSciencePublishers, New York, 23-30.

Thyssen, J., Linneberg, A., Menne, T., Johansen, J. (2007). The epidemiology of contact allergy in the general population - prevalence and main findings. Contact Dermatitis, 57(5):287-299.

Todd, G., Kay, J. (2016). Gadolinium-induced fibrosis. Annual Review of Medicine, 67, 273-291.

Verevka, S.V. (2017). The Main Parametabolic Complex / In: Advances in Medicine and Biology (Berhardt L.V., Ed.), Nova Science Publishers, New York, 126, 181-200.

Voroshylova, N.M., Timchenko, M.D., Verevka, S.V. (2019). Bence-Jones protein as a form of nano-scaled $\beta$-stacked supramolecular aggregates. Ukrainian Journal of Nephrology and Dialysis, 4, 39-44.

Wagner, B., Drel, V., Gorin, Y. (2016). Pathophysiology of gadolinium-associated systemic fibrosis. American Journal of Physiology. Renal Physiology, 311, 1-11.

Zabolotnyi, D.I., Belousova, A.A., Zabolotna, D.D., Savchenko, T.D., Voroshylova, N.M., Timchenko, M.D., Tsvirinko, I.R., Verevka, S.V. (2019). Aggregated proteins in malignant and benign neoplasms. Experimental Oncology, 41, 61-68.

Zabolotnyi, D.I., Sambur, M.B., Voroshylova, N.M., Verevka, S.V. (2019). Extracellular components of biofilms in the formation of antibiotic resistance and chronicity of the inflammatory processes. State of the problem. Otorhinolaryngology, 2-3, 72-84. [in Ukrainian].

Zabolotny, D.I., Verevka, S.V. (2009). Inter-molecular coordination of proteins at normal and pathologic state / In: Molecular Pathology of Proteins (Zabolotny D.I., Ed.), Nova Science Publishers, New York.

Zabolotny, D.I., Dieieva Yu.V., Gurzhenko Yu.M., Zabolotna D.D., Gordiienko Iu.A., Tymchenko M.D., Voroshylova N.M., Pakrishen S.V., Verevka, S.V. (2021). Fibrosis: polyetiologic complication with common denominator. Journal of National Academy of Medical Sciences of Ukraine, 27, 90-99. [in Ukrainian]. 


\section{МЕТАЛ-ІНДУКОВАНА ДЕНАТУРАЦІЯ БІЛКІВ: ЗАКОНОМІРНОСТІ, ПАТОЛОГІЧНІ ПРОЯВИ ТА МОДЕЛЮВАННЯ INVITRO.}

\section{Попович Тетяна ${ }^{1}$, Кізім Ярослав $^{2}$, Оберніхіна Наталя ${ }^{3}$, Ворошилова Наталя ${ }^{4}$}

${ }^{1}$ Студентка 5 курсу Національного медичного університету ім. О.О. Богомольця

${ }^{2}$ Молодший науковий співробітник відділу онкопатології ЛОР органів Інституту отоларингології ім. проф. О.С Коломійченка НАМН України,

${ }^{3}$ Доцент кафедри біохімії Національного медичного університету ім. О.О. Богомольця,

${ }^{4}$ Кандидат хімічних наук, старший науковий співробітник лабораторії біохімії Інституту отоларингології ім. проф. О.С Коломійченка НАМН України, кандидат біологічних наук.

Анотація: здатність іонів багатьох металів до комплексоутворення з білками призводить до денатурації останніх та розвитку імунної відповіді на подібні структурно ушкоджені білки. Подібна гаптенова дія обумовлює загальновідомий феномен нікель-алергічного контактного дерматиту. В останні роки дедалі більшої уваги зазнають побічні ефекти сполук гадолінію, що використовуються в ролі контрастерів магнітної резонансної томографіï, однак індукують розвиток фіброзу. В обох випадках важлива роль належить взаємодії іонів металу з колагеновими структурами. Ціль нашого дослідження полягала в порівнянні за умов in vitro впливу іонів міді та нікелю на дестабілізовані продукти розщеплення колагену. Показано істотні відміни між цими металами щодо здатності індукувати агрегацію за значень $\mathrm{pH}$, що наближені до фізіологічних. Виявлено вплив на процес агрегації закиснення середовища. Показано, що порушення структури білка призводить до утворення високостабілізованих $\beta$-складчастих білкових агрегатів. Порівняння отриманих експериментальних даних з даними літератури дає змогу наблизитись до розуміння окремих механізмів токсичного впливу іонів металів на організм людини.

Ключові слова: гаптенові ефекти, токсичність металів, денатурація білків, алергії, фіброз. 